DOI: $10.15290 / \mathrm{bsl} .2021 .18 .12$

\author{
Katarzyna Trusewicz \\ Kolegium Literaturoznawstwa \\ Wydział Filologiczny \\ Uniwersytet w Białymstoku \\ e-mail: katarzynatrusewicz@gmail.com \\ ORCID: 0000-0003-3982-1642
}

\title{
Przyroda w perspektywie nieantropocentrycznej. O Sadze Puszczy Białowieskiej Simony Kossak
}

Najważniejszym miejscem pracy naukowej, działalności popularyzatorskiej oraz życia prywatnego Simony Kossak była Puszcza Białowieska. Badaczka oraz pisarka, mieszkając ponad trzydzieści lat w leśniczówce Dziedzince bez prądu oraz bieżącej wody, każdego dnia uczyła się życia z nie-ludzkimi mieszkańcami ostatniej prastarej puszczy. Zdając sobie sprawę z niewielkiej świadomości polskiego oraz międzynarodowego społeczeństwa o postępującym negatywnym wpływie antropopresji na Puszczę Białowieską, Kossak postanowiła nagłośnić problem za pośrednictwem literatury. Swoją aktywność popularyzatorską realizowała za pośrednictwem radiowych gawęd ${ }^{1}$ oraz opowiadań ${ }^{2}$, których głównymi bohaterami są rośliny oraz zwierzęta. W książce Saga Puszczy Białowieskiej³, ukazującej tytułową Puszczę

\footnotetext{
1 Simona Kossak w latach 2001-2007 na antenie Polskiego Radia Białystok wygłosiła prawie dwa tysiące gawęd dotyczących tematyki przyrodniczej. Gawędy nie zostały przez ich autorkę spisane, jednak po jej śmierci pojawiło się kilka albumów z radiowymi opowieściami Kossak.

2 S. Kossak, Opowiadania o ziołach i zwierzętach. Zgodnie z natura swojego gatunku, Warszawa 1995. Wydawnictwo Marginesy wznowiło opowiadania Kossak w serii EKO pod zmienionym tytułem: S. Kossak, O ziołach i zwierzętach, Warszawa 2017.

3 S. Kossak, Saga Puszczy Białowieskiej, Warszawa 2001. Ze względu na utrudniony dostęp do pierwszego wydania, korzystam ze wznowienia Sagi z 2016 roku, opublikowanego przez wydawnictwo Marginesy. Lokalizację cytatów z książki podaję w tekście głównym, oznaczając je skrótem $S P B$.
} 
z perspektywy nieantropocentrycznej, Kossak sięga po inny tradycyjny gatunek - sagę. Za jej pośrednictwem autorka stara się zapoznać czytelników z wielowiekową historią puszczańskiej przyrody, a zarazem uwrażliwić ich na problemy, z którymi Puszcza Białowieska mierzyła się na przełomie XX oraz XXI wieku.

W aspekcie genologicznym saga określana jest jako „opowieść prozą przedstawiająca losy znanego - z legend lub historii - bohatera lub dzieje wybitnego rodu"4. U źródeł gatunku leżą staroislandzkie opowieści epickie z XIII wieku, w których przedstawiano najpierw ustnie, a następnie w formie pisemnej, losy bohaterów lub całych rodów. Przez współczesną sagę rozumie się głównie obszerne utwory epickie, opisujące dzieje kilku pokoleń konkretnej rodziny ${ }^{5}$. Simona Kossak, podobnie jak czyniła to, pisząc gawędy ${ }^{6}$, sięga po „wymierający” gatunek literacki i wykorzystuje go, aby opowiadać o wielopokoleniowej puszczańskiej przyrodzie. Saga Puszczy Białowieskiej stanowi przykład twórczej modyfikacji gatunku, gdyż autorka skupia się na historii tragicznej $\mathrm{w}$ skutkach ingerencji człowieka $\mathrm{w}$ środowisko przyrodnicze. Przyjęta przez Kossak perspektywa mówienia o konkretnym miejscu, jakim jest Puszcza Białowieska, stoi w opozycji do dotychczasowych propozycji badaczy jej historii, wśród których najważniejsze miejsce zajmuje Otton Hademann (1887-1937), autor Dziejów Puszczy Białowieskiej $w$ Polsce przedrozbiorowej ( $w$ okresie do 1798 roku) ${ }^{7}$. Książka została opublikowana dwa lata po śmierci autora, który „zmarł w trakcie zapamiętałej,

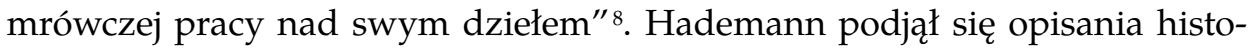
rii Puszczy Białowieskiej na zlecenie Instytutu Badawczego Lasów Państwowych ${ }^{9}$. We wstępie do książki tak oto scharakteryzował przedmiot swoich badań:

Temat nasz ze stanowiska historii posiada dwie specyficzne cechy. Po pierwsze puszcza, jako taka, nie jest właściwie tematem dla historyka. Podmiotem i przedmiotem bowiem nauki historii jest człowiek, a i to tylko od chwili, gdy

\footnotetext{
4 Hasło: „saga”, w: M. Głowiński, T. Kostkiewiczowa, A. Okopień-Sławińska, J. Sławiński, Słownik terminów literackich, Wrocław 1988, s. 454.

5 Tamże.

6 Zob. K. Trusewicz, Ekogawędy Simony Kossak, „Białostockie Studia Literaturoznawcze” 2016, nr 9, s. 95-105.

7 O. Hademann, Dzieje Puszczy Białowieskiej w Polsce przedrozbiorowej (w okresie do 1798 roku), Warszawa 1939.

8 Przedmowa, w: O. Hademann, Dzieje Puszczy Białowieskiej w Polsce przedrozbiorowej (w okresie do 1798 roku), s. 5 .

9 Zob. hasło: Hademann Otton (1997-1937), w: Encyklopedia Puszczy Białowieskiej, http:// www.encyklopedia.puszcza-bialowieska.eu/index.php?dzial=haslo\&id=397 [dostęp 9.03.2021].
} 
występuje jako jednostka zorganizowana w społeczeństwie. Samo zaś terytorium niezaludnione interesuje szereg innych nauk - jak geologię, geografię, hydrografię botanikę, zoologię itd. To też Puszcza Białowieska ze stanowiska historii interesuje nas od chwili, gdy ukazał się w niej człowiek ${ }^{10}$.

Przyjęta przez badacza postawa antropocentryczna skutkuje tym, że opisując dzieje Puszczy Białowieskiej, skupia się on na przedstawieniu działań człowieka prowadzących do pomniejszania jej obszaru. Hademann zauważa bowiem, że „historia Puszczy Białowieskiej będzie (zwłaszcza do początków wieku XIX) historią jej zmierzchu" 11. Jednocześnie stwierdza, że krytyka wycinania kolejnych połaci pierwotnych lasów nie jest uzasadniona:

zarzut barbarzyństwa, niszczycielstwa, trwonienia bogactw narodowych z perspektywy historii nie ma znaczenia, nie może obciążać naszych przodków, znajdujących się w takiem stadium rozwojowem (sic!), któremu podobne zagadnienia były obce. Nadto im dalej w głąb wieków, tym bardziej owo „niszczenie” lasów było czynnikiem niezbędnym dla rozwoju i konsolidacji społeczeństw, z tego prostego powodu, że puszcza opanowała glob ziemski wcześniej, iż ukazały się zorganizowane i walczące o swój byt społeczeństwa ${ }^{12}$.

Z odmiennym rozumieniem związków z puszczą spotykamy się na kartach Sagi Puszczy Białowieskiej, której autorka postrzega człowieka jako destrukcyjnego intruza. Na wyższościową postawę człowieka wobec przyrody, zauważalną także u Hademanna, wskazuje Aleksandra Ubertowska w artykule Pisanie Puszczy:

Już sama dynamika historii środowiskowej sytuuje puszczę w relacji wrogiej opozycji wobec świata ludzkiego. [...] kultura neolityczna i cywilizacja pierwszych państw-miast wyłoniła się wbrew napierającej sile pierwotnych lasów, które odrodziły się po ostatnim zlodowaceniu i zmusiły społeczności nomadów do „wyrąbywania” w gąszczu drzew miejsc do osiedlenia. Pozostałości selva antica wyznaczały zawsze skraj, obrzeża kruchej cywilizacji, której groziło ponowne osunięcie się w chaos, dzikość, niezróżnicowanie. Reforestyzacja była więc upiornym wariantem historii, realnie zagrażającym strukturom pierwszych cywilizacji ${ }^{13}$.

O możliwości naturalnej reforestyzacji pisze Kossak w Sadze Puszczy Białowieskiej w opowiadaniu Ona, dotyczącym epidemii dżumy. Choroba ta pojawiła

\footnotetext{
10 O. Hademann, Dzieje Puszczy Białowieskiej w Polsce przedrozbiorowej (w okresie do 1798 roku), s. 17.

11 Tamże, s. 18.

12 Tamże, s. 17-18.

13 A. Ubertowska, Pisanie puszczy. Ekonomie dyskursu ekokrytycznego i postkolonialnego, „Teksty Drugie" 2017, nr 6, s. 195.
} 
się w Białowieży w 1710 roku, sprowadzona przez „kupców przybywających z zapowietrzonych stron" [SPB, s. 185]. „Zwarta ściana lasu napierająca na Białowieżę" [SPB, s. 179] mogłaby stanowić ochronę przed chorobą przywiezioną przez handlarzy, jednak miejscowa ludność, nie zdając sobie sprawy z nadchodzącego zagrożenia, wycina kolejne ostępy Puszczy. Jak pisze Kossak, „w krótkim czasie większość mieszkańców puszczańskich wsi i osad zmarła", a pamiątką tego wydarzenia jest możliwy do zaobserwowania w Puszczy „wał ziemi kryjący zbiorową mogiłę zadżumionych” [SPB, s. 185]. Epidemia dżumy doprowadziła do śmierci większości mieszkańców puszczańskich wiosek, a nieliczni „uratowani z pogromu spalili wieś i założyli nowe osady" [SPB, s. 185]. Procesy związane z nieustanną wycinką Puszczy Białowieskiej zostały chwilowo zatrzymane w związku ze śmiercią jej ludzkich mieszkańców w efekcie panującej epidemii.

Wpływ działalności człowieka na zmiany zachodzące w Puszczy Białowieskiej stanowi obiekt badań naukowych Tomasza Samojlika, pracownika Instytutu Biologii Ssaków Polskiej Akademii Nauk w Białowieży. Samojlik prowadzi swoje badania $w$ ramach historii przyrodniczej (ang. environmental lub ecological history), dziedziny znajdującej się na pograniczu historii oraz przyrody, powstałej w latach siedemdziesiątych w Zachodniej Europie i Ameryce Północnej. Jak sam wyjaśnia, historia przyrodnicza:

korzysta z metod badawczych właściwych dla biologii, ekologii i innych nauk przyrodniczych, a także historii, archeologii i geografii. Jej dynamiczny rozwój łączy się z coraz większą społeczną świadomością, że skutki naszych działań i decyzji dotyczących środowiska będą widoczne i odczuwane dopiero w przyszłości ${ }^{14}$.

Samojlik, analizując rolę człowieka w kształtowaniu terenów nieleśnych Białowieskiego Parku Narodowego, wyróżnia pięć antropogenicznych przemian lasu'15, a w książce Ochrona $i$ łowy. Puszcza Białowieska w czasach królewskich podaje argumenty na rzecz odmiennego rozumienia lasu pierwotnego i pradawnego. Pojęcie lasu pradawnego (ancient forest) odnosi się do drzew rosnących na tym samym miejscu co najmniej od 400 lat. Las pierwotny (primeval forest) charakteryzuje brak lub nieznaczna ilość wyrębów udokumentowanych w przeszłości, obecność dużej liczby martwych drzew i rozkładającego

14 Ochrona i łowy. Puszcza Białowieska w czasach królewskich, red. T. Samojlik, Białowieża 2005, s. 7.

15 Por. T. Samojlik, B. Jędrzejewska, D. Krasnodębski, Badania archeologiczne w Puszczy Białowieskiej. Ocena przeszłego wpływu człowieka na środowisko leśne (poster), w: Dziedzictwo kulturowe w lasach. Program III konferencji naukowej „Konserwacja zapobiegawcza środowiska”, Warszawa, 24-25.10.2013. 
się drewna, powszechne występowanie roślin, mchów, porostów, grzybów i zwierząt wrażliwych na wpływ człowieka oraz wielka różnorodność gatunków ${ }^{16}$. Pojęcie lasu pradawnego zostało stworzone na gruncie badań prowadzonych w Wielkiej Brytanii na początku XX wieku, gdzie tereny zalesione stanowiły jedynie $11 \%$ obszaru terytorialnego. Określenie "las pradawny" odnosi się nie tyle do wieku drzew, ile do formy wykorzystania terenu. Definicja ta nie bierze pod uwagę naturalności lasów ani różnorodności gatunkowej, a na Zachodzie przez las pradawny rozumie się wszelkie istniejące od dawna lasy. Z kolei pojęcie lasu pierwotnego zrodziło się i funkcjonuje na obszarze Europy Środkowej, Wschodniej i Północnej, gdzie gęstość zalesienia waha się od 28 do nawet $86 \%$. Badania palinologiczne (analiza pyłków roślin kwiatowych osadzonych na pokładach torfu) w Puszczy Białowieskiej wykazały, że odlesienie od czasów lodowcowych nie przekroczyło $15 \%$. Na miano lasu pierwotnego zasługuje zatem niewielka centralna część Puszczy, obejmująca około $50 \mathrm{~km}^{2}$, która, jak zauważa Samojlik, "chroni ostatnie szczątki pierwotnych puszcz europejskich nizin" ${ }^{\prime 17}$.

Wyniki badań z zakresu nauk ścisłych warto skonfrontować z wyobrażeniem Puszczy Białowieskiej jako miejsca pierwotnego, niedostępnego, zakrytego, zamkniętego oraz ukrytego, tworzonym przez lata również dzięki literaturze. Anna Barcz w książce Realizm ekologiczny zauważa:

dostrzeżenie przez Mickiewicza matecznika puszczy, niezależnego od człowieka, tajemniczego i niedającego się oswoić, z zamieszkującymi go wówczas, a dziś wymarlymi turami, czy obecnie chronionymi z uwagi na niewielką liczebność - żubrami i niedźwiedziami, przypomina opis ścisłego rezerwatu, do którego człowiek nie powinien wchodzić ${ }^{18}$.

Barcz rozumie przyrodę jako byt zasługujący na własną autonomię. Badaczka podkreśla, że środowisko naturalne nie powinno stanowić obiektu ciągłej ingerencji człowieka, co ma miejsce w rzeczywistości. Empiryczne badania, prowadzone przez przyrodników w Puszczy Białowieskiej, utożsamianej z mickiewiczowskim matecznikiem, burzą jej obraz jako przestrzeni nietkniętej ludzką ręką. Wyniki badań z zakresu historii przyrodniczej przedstawione przez Samojlika pokazują, jak niewielka część Puszczy Białowieskiej zachowała pierwotny charakter. O znikomej presji antropogenicznej na terenie Puszczy Białowieskiej możemy mówić tylko w przypadku okresu dziesięciu wieków (VI-XVI) oraz od 1921 roku, kiedy to powstał Białowieski

\footnotetext{
16 T. Samojlik, Ochrona i łowy, s. 18.

17 Tamże.

18 A. Barcz, Realizm ekologiczny. Od ekokrytyki do zookrytyki w literaturze polskiej, Katowice 2016, s. 60 .
} 
Park Narodowy. Największy wpływ człowieka na Puszczę zarejestrowano w okresie międzywojennym, kiedy firma The European Century Timber Corporation eksploatowała las. Liczne łowy doprowadziły do całkowitego wyginięcia żubra - w 1919 roku, a ostatni żubr został zabity przez kłusownika. W 1929 roku miała miejsce restytucja żubra na bazie kilku osobników ocalałych w hodowlach i ogrodach zoologicznych.

W artykule Las a rozwój człowieka w dziejach cywilizacji (na przykładzie Puszczy Białowieskiej) Samojlik podejmuje problem roli lasu w życiu jego mieszkańców oraz w rozwoju kultury i cywilizacji. Badacz zwraca uwagę, że:

po raz pierwszy skuteczną, masową i rabunkową eksploatację zasobów drzewnych wprowadziły dopiero wojska niemieckie podczas I wojny światowej w 1915 roku. W 1921 roku dla ochrony najlepiej zachowanych i najcenniejszych fragmentów Puszczy powstał pierwszy rezerwat, przekształcony później w Białowieski Park Narodowy ${ }^{19}$.

Rozważaniom Samojlika towarzyszy przeświadczenie o silnym wpływie postępu cywilizacyjnego na zmiany zachodzące w Puszczy Białowieskiej zarówno w zakresie gospodarki leśnej, jak również praktyki życia w Puszczy. Badacz zauważa, że lata życia i funkcjonowania w lesie doprowadziły do wykształcenia się tradycyjnej działalności leśnej, a przykładem tego typu zjawisk jest bartnictwo ${ }^{20}$.

Legenda bartnictwa jest silnie zakorzeniona w mitologii Puszczy Białowieskiej. Odnosi się do niej również Simona Kossak w Sadze Puszczy Białowieskiej, stwierdzając, że: „Bartnictwo, poza korzyściami płynącymi do skarbu królewskiego i prywatnych kieszeni, szkodziło lasom" [SPB, s. 198]. Ta negatywna ocena bartnictwa wynika głównie z faktu, iż powodowało ono pożary, które, zdaniem Kossak, były "największymi klęskami spadającymi na lasy” [SPB, s. 223].

Simona Kossak w Sadze Puszczy Białowieskiej odwołuje się do historii i legend związanych z opisywanym przez nią miejscem. Radosław Romaniuk w recenzji Sagi Puszczy Białowieskiej pod tytułem Samotny mamut oprócz wielu zalet omawianej książki wskazuje jako wadę jej konstrukcję:

nie sposób niestety pominąć defektów konstrukcyjnych książki. Nieoddzielone typograficznym światłem poszczególne akapity, dotyczące spraw nieraz tak różnych, jak panująca w latach 1953-54 pryszczyca, głos sprzeciwu wobec planów

19 T. Samojlik, Las a rozwój człowieka w dziejach cywilizacji (na przykładzie Puszczy Białowieskiej), w: Las jako czynnik rozwoju cywilizacji: wspótczesna i przyszła wartość lasów, red. Rykowski i in., Sękocin Stary 2014, s. 173.

20 Zob. J. Lelewel, Pszczoly i bartnictwo w Polszcze, Poznań 1856; P. Dąbkowski, Bartnictwo w dawnej Polsce. Szkice gospodarczo-prawne, Lwów 1923. 
odstrzału żubrów i nekrolog leśnika, wprowadzają w tok gawędy nieprzystojny gatunkowi chaos informacyjny. Czytelnikowi poszukującemu wśród tych migotliwych akapitów całości pozostaje nadzieja, że owe fragmenty Sagi nie są przypadkową zbitką popularnonaukowych felietonów, że samą książkę trzeba traktować jako księgę, której patronuje przemyślny nieporządek natury, nie zaś porządek literackiej kompozycji; kronikę, do której wkleja się informacje o historii, pogodzie, botanice, dokumenty, listy, zdjęcia, wspomnienie o wypielęgnowanych od narodzin łoszakach „Pepsi” i „Koli”, fragmenty publicystyczne, opowiadania $^{21}$.

Autor recenzji, pisząc o kompozycji Sagi jako opartej na „wklejaniu” rozmaitych informacji i łączeniu różnych form wypowiedzi, nieświadomie przedstawił książkę jako sylwę. Charakter zastosowanej w niej narracji nawiązuje, jak sądzę, do sylw domowych, popularnych w domach szlacheckich ksiąg, z którymi Kossak, krakowianka z domu o szlacheckiej proweniencji, zapewne była zaznajomiona. Proponuję zatem interpretację Sagi Puszczy Białowieskiej w kontekście kategorii sylwiczności, wprowadzonej przez Ryszarda Nycza na potrzeby analizy współczesnych utworów literackich, w przypadku których trudno jest wyznaczyć wyraźne ramy gatunkowe. Punktem wyjścia rozważań Nycza nad sylwicznością tekstu był artykuł Stefanii Skwarczyńskiej, w którym analizowała ona genezę oraz strukturę rękopisów funkcjonujących pod nazwą silva rerum ${ }^{22}$. Łacińskie słowo silva oznaczające "las” "każe uznać [...] różnorodność oraz względną autonomię elementów za dominującą cechę tekstu, która obejmować może - zarazem lub z osobna - konstrukcje językowo-stylistyczne, tematyczne, kompozycyjne i gatunkowe" ${ }^{23}$. Różnorodność lasu staje się tym samym metaforą, określającą tekst literacki o charakterze hybrydowym. Saga w realizacji Kossak jest gatunkiem warunkowanym przestrzenią leśną, a więc powiązanie tego gatunku z sylwą odsyła do jej pierwotnego znaczenia. Metaforyczne rozumienie „lasu rzeczy” przekłada się na stylistykę i kompozycję Sagi oraz odsyła do źródła gatunku - metafory. Posługując się sylwą, Kossak przypomina o związku myślenia metaforycznego z krajobrazem i miejscem, którego się doświadcza. Zależność między metaforą i doświadczeniem, leżąca u podstaw wykorzystanego przez Kossak nawiązania, nie pozostaje wyłącznie intertekstualnym gestem, gdyż wynika z subiektywnego doświadczenia autorki, która w Puszczy mieszkała ponad trzydzieści lat.

21 R. Romaniuk, Samotny mamut, „Nowe Książki” 2002, nr 7-8, s. 13.

22 Zob. S. Skwarczyńska, Kariera literacka form rodzajowych bloku silva, w: Wokót teatru i literatury. Studia i szkice, Warszawa 1970, s. 182-202.

23 R. Nycz, Sylwy współczesne. Problem konstrukcji tekstu, Wrocław 1984, s. 9-10. 
Dziewięć lat przed premierą Sagi Puszczy Białowieskiej Simona Kossak na łamach "Gazety Wyborczej" opublikowała artykuł Śmierć puszczy, będący apelem skierowanym do czytelnika, który powinien pamiętać, że dusza Puszczy „wygnana z próchniejącego pnia płacze w ostatnich ostojach" ${ }^{24}$. Emocjonalnie nacechowana wypowiedź Kossak rozpoczyna również Sagę Puszczy Białowieskiej, w której autorka przywołuje cytowany wyżej artykuł. Przez niespełna dziesięć lat, jakie dzielą apel Kossak na łamach „Gazety Wyborczej” od ukazania się Sagi Puszczy Białowieskiej, opinia badaczki o zachowaniach ludzi wobec Puszczy nie uległa zmianie. Kossak podkreśla, że chociaż Puszcza „leżąca na pograniczu krajów i narodów, ukryta wśród bagien - przetrwała”, to "na oczach naszego pokolenia rozgrywa się ostatni akt jej dziejów" [SPB, s. 13]. Centrum narracji stanowi problem wymierania głównych, nie-ludzkich bohaterów, takich jak żubr, rosomak, łoś czy ryś, spowodowany rozwojem cywilizacyjnym. Bohaterowie zwierzęcy uwikłani są w wielką historię Polski - dzieje jelenia opisane zostały w kontekście poczynań króla Sasa, a dzieje niedźwiedzia na tle rządów Jagiełły. Bohaterowie poboczni kuny, lisy czy zające - zdobią co najwyżej królewskie szaty swoim futrem.

Pojemna forma sagi pozwoliła autorce na przekazanie wieloaspektowej historii Puszczy Białowieskiej, co wymagało sięgnięcia do różnych źródeł wiedzy. Warsztat badawczy Kossak, zbudowany na wieloletnim doświadczeniu naukowym, odsyła ją do książek i podań historycznych, jednak okazuje się, że:

piśmiennictwo poświęcone najnowszym dziejom Puszczy Białowieskiej i jej zwierząt [...] zamiast być pomocą w poszukiwaniu prawdy, wyprowadza na manowce. [...] Brane za dobrą monetę i cytowane przez kolejnych piszących wnet stają się obowiązującą prawdą - potwierdzając opinię, że to historycy tworzą historię [SPB, s. 423].

$\mathrm{Z}$ tego też powodu Kossak czerpie informacje zarówno $\mathrm{z}$ archeologii, historii czy geologii ${ }^{25}$, jak i z przekazów ludowych, w tym ustnych, związanych z jej codziennym życiem w Puszczy Białowieskiej ${ }^{26}$. Pisząc o historii Puszczy Białowieskiej, Kossak rozmontowuje legendę opiekuńczych władców, pokazując ich jako okrutnych myśliwych polujących na puszczańskie zwierzęta. Przywołuje również fakty przedstawiające $\mathrm{w}$ złym świetle działania polskiego

\footnotetext{
24 S. Kossak, Śmierć puszczy, "Gazeta Wyborcza” 1992, nr 136, s. 12.

25 Zob. „W Wyszogrodzie archeolodzy odkryli klasyczne sanktuarium prasłowiańskie”, S. Kossak, $S P B$, s. 48.

26 „Stara anegdota rodem z Białowieży mówi, że gdy car po raz pierwszy ujrzał będące już na ukończeniu dzieło młodego architekta, swe estetyczne wrażenia skwitował jednym słowem: «Naplewat!»” [SPB, s. 311-312]; „Bajarze bają” [SPB, s. 384].
} 
rządu w czasie wycinki Puszczy przez firmę Century. Dokonana przez Kossak analiza prasy fachowej z lat 1920-1939 pokazuje, że państwo polskie wcale nie zostało oszukane przez angielską firmę [SPB, s. 320-321]. Wspó1czesne sobie wydarzenia i negatywne zachowania osób odpowiedzialnych za ochronę Puszczy Białowieskiej autorka Sagi komentuje następująco:

Pozostawmy przyszłości sprawiedliwą ocenę tych, którzy dziś, stojąc na świeczniku, wiele mogą dla Puszczy uczynić, a nie czynią nic, i tych przekonanych, że już im się pomnik należy, jak i tych, którzy w pełni zasłużyli na szacunek i wdzięczność przyszłych pokoleń. Niech z dystansu minionego czasu przyszli szperacze po archiwach, bibliotekach i ludzkiej pamięci oddzielą ziarna od plew [SPB, s. 421].

Stawiając sobie za cel odkrycie prawdy o wielowiekowym oddziaływaniu człowieka na kształt Puszczy Białowieskiej, Kossak przyjmuje postawę „szperacza po archiwach, bibliotekach i ludzkiej pamięci”. Wiarygodność przekazu historycznego jest dla niej bardzo istotna, o czym świadczą cztery rozdziały sagi mające charakter wyłącznie faktograficzny (Eksploatacja, Pladrowanie, $U$ progu trzeciego tysiąclecia oraz Siła argumentów). Na szczególną uwagę zasługuje rozdział $U$ progu trzeciego tysiąclecia, w którym Kossak, opisując wycinkę Puszczy na przestrzeni lat, nazywa tę czynność za pomocą różnych określeń i pokazuje w ten sposób, jak zmienia się metoda wycinania drzew ze względu na stopień technologicznego zaawansowania:

Rok 1950. (Zgrzytają piły, Puszczę Białowieską rozjeżdżają konne zaprzęgi i ciągniki przystosowane do wywózki dłużyc i innych sortymentów drzewa.) [...] Rok 1956. (Zgrzytają piły...) [...] Rok 1958. (Zgrzytają piły ręczne, warczą piły mechaniczne...) [...] Rok 1961. (Warczą piły...) [...] Rok 1975. (Warczą piły, Puszczę rozjeżdżają coraz większe i coraz doskonalsze maszyny przystosowane do wywózki różnych sortymentów drewna [SPB, s. $428-437$, podkr. - K.T.].

$\mathrm{Z}$ kolei $\mathrm{w}$ ostatnim rozdziale, Sile argumentów, Kossak cytuje pisarzy i osoby związane $\mathrm{z}$ toczącą się u progu XXI wieku dyskusją zogniskowaną wokół ochrony Puszczy Białowieskiej. Jak zauważa Magdalena Lachman, „przyrodoznawcy widzą obecnie potrzebę wspierania się na różne sposoby autorytetami pisarskimi oraz doceniają poznawczą i dydaktyczną moc cytatów czy w ogóle wypowiedzi literackich" ${ }^{27}$. W kontekście pisarstwa skoncentrowanego wokół problemów Puszczy Białowieskiej nie jest to zjawisko

27 M. Lachman, Gdzie jest przyroda, jak jej... nie ma? Rzut oka na przypadek literacki, „Kultura Współczesna" 2011, nr 1, s. 147. 
nowe, ponieważ już na przełomie XIX i XX wieku badacze posługiwali się literaturą piękną w celu przekazania wiedzy o roślinach i zwierzętach. Podobnie Kossak, zarówno w swoich opowiadaniach, jak i w Sadze posługuje się cytatami $z$ literatury.

Poszczególne rozdziały Sagi charakteryzuje dwudzielna konstrukcja. W pierwszej części czytelnik konfrontuje się z wydarzeniami i faktami ujętymi w formie krótkiego, literackiego przekazu, który sama autorka określa opowiadaniem. Na przykład po literackiej opowieści o polowaniu zorganizowanym przez cara Aleksandra II w 1860 roku w Puszczy Białowieskiej pojawia się faktograficzny komentarz, w którym autorka wyjaśnia: „Opis wydarzeń, na podstawie którego osnułam opowiadanie Zwierzyniec, zawdzięczamy naocznemu świadkowi - carskiemu dworakowi Dałmatowowi" [SPB, s. 250] $]^{28}$. Prowadzenie dwóch planów narracyjnych ma na celu podkreślenie wspólnoty ludzkich i zwierzęcych losów. Przykładem jest opowiadanie Zagłada Jaćwingóww, w którym Kossak przedstawia historię wyniszczenia ludu Jadźwingów oraz tarpanów. Wyginięcie opisywanego ludu i zwierząt zostało ze sobą powiązane, dzięki czemu czytelnik dostrzega wspólnotę losów dwóch różnych gatunków. Według Joanny Durczak, badaczki zajmującej się przyrodopisarstwem amerykańskim, strategia przyjęta przez Kossak:

służy osiągnięciu celu bardzo podobnego do tego, który przyświeca przyrodopisarstwu, a mianowicie - przybliżeniu wyobraźni suchych faktów przez ocieplenie ich siecią asocjacji i emocjonalnych znaczeń. Jednakże ostateczny efekt tego zabiegu nie jest identyczny $\mathrm{w}$ obu przypadkach. Podczas gdy $\mathrm{w}$ tradycyjnym przyrodopisarstwie następuje wtopienie materii faktograficznej w opowieść o jej subiektywnym poznaniu, u Kossak ta fuzja nie następuje. Dwa rodzaje dyskursu - literacki i popularnonaukowy - pozostają w Sadze wyraźnie, także wizualnie, rozdzielone i rozgraniczone. Autorka poniekąd pozostawia czytelnikowi wybór. Ten może przeczytać książkę zgodnie z autorskim zamysłem, czyli w naprzemiennych sekwencjach: opowiadanie-komentarz popularnonaukowy. Ale może też - jeśli na przykład nie gustuje w dość tradycyjnej prozie historycznej - przeczytać wyłącznie fragmenty popularnonaukowe i w ten sposób niejako zignorować intencję zespolenia w książce wiedzy, uczuć i wyobraźni ${ }^{29}$.

Durczak uwzględnia różne tryby czytania książki Kossak. Należy podkreślić, że w przypadku wyboru przez czytelnika wyłącznie lektury jednej $\mathrm{z}$ części, odbiorca rezygnuje z możliwości zagłębienia się w liczne niuanse

28 Również: „Straszliwa burza opisana w opowiadaniu Przygoda szalała nad Puszczą drugiego i trzeciego sierpnia" [SPB, s. 267].

29 J. Durczak, Rozmowy z ziemia. Tradycja przyrodopisarska w literaturze amerykańskiej, Lublin 2010, s. 241. 
i utkaną przez autorkę sieć zależności pomiędzy poszczególnymi warstwami tekstu.

W Sadze Puszczy Białowieskiej wyraźny jest subiektywny stosunek Kossak do Puszczy Białowieskiej. Pojawiają się więc na przykład historie o ukochanych przez nią sarnach oraz łosiach Pepsi i Kola, które przez długi czas miała pod opieką. O silnym subiektywizmie książki Kossak świadczy powód jej napisania. Wyrasta bowiem ona z ogromnego przywiązania autorki do Puszczy, a celem Sagi jest zwrócenie uwagi na problem stopniowego wyniszczania przez człowieka opisywanego miejsca.

Zjawisko stopniowego zanikania lasów na rzecz terenów użytkowanych przez człowieka w ramach m.in. rolnictwa, przemysłu czy gospodarki leśnej stanowi źródło naukowych zainteresowań badaczy historii środowiskowej. Alexander Mather w książce South-North Challenges in Global Foresty przedstawia trzystopniowy model historii użytkowania lasu w Europie. Badacz wyróżnia okres preindustrialny, kiedy wpływ człowieka na leśny ekosystem był znikomy. Kolejny etap rozpoczyna się około 1750 roku i jest związany ze zjawiskiem rewolucji przemysłowej. W okresie tym, nazywanym przez Mathera industrialnym, las traktowany jest przez człowieka jak fabryka drewna. Pod koniec XX wieku „las zaczął być postrzegany nie jako źródło drewna, a jako skomplikowana biologicznie całość, rządząca się prawami, których zrozumienie może pozwolić na pogodzenie konieczności korzystania z lasu i chęci jego zachowania" 30 i od tego momentu można mówić o lesie postindustialnym. Kossak podkreśla, że obecna Puszcza Białowieska jest jedynie skromną pozostałością po ogromnych połaciach prapuszczy, ponieważ, jak stwierdził Hademann, „historia lasów jest niczym innym, jak obrazem ich zaniku, zmierzchu" ${ }^{31}$. Autorka pisze jednak, że pomimo swojej wieloletności „puszcza nigdy nie była i nigdy nie będzie stara. Ona, nieporuszona $\mathrm{w}$ swym ponadczasowym majestacie, trwa w opływających ją tysiącleciach wciąż tak samo żywotna" [SPB, s. 27]. Badaczka podkreśla również, że puszcza „przez tysiąclecia powstawała z resztek obumarłych roślin i zwierząt, karmiła nowe życie, rodząc i grzebiąc kolejne generacje ziól, krzewów i olbrzymich drzew" [SPB, s. 26]. Kossak przedstawia więc dzieje Puszczy w perspektywie wielowiekowego cyklu życia, który miał swój początek w prapuszczy. Puszcza Białowieska przetrwała, a razem z nią pamięć o pradawnych roślinach i zwierzętach, które za sprawą działalności człowieka, ale również

30 Za: T. Samojlik, Las a rozwój człowieka w dziejach cywilizacji (na przykładzie Puszczy Białowieskiej), s. 175.

31 O. Hademann, Dzieje Puszczy Białowieskiej w Polsce przedrozbiorowej (w okresie do 1798 roku), s. 17. 
zmian klimatycznych, wyginęły na przestrzeni wieków. Jak bowiem zauważa Kossak, ,[z] każdego załomka głęboko spękanej kory dębu, z każdej dziupli, z każdego osnutego mgłami bagniska tchnie pamięć dawno minionych lat" [SPB, s. 27]. Badaczka na kartach Sagi wielokrotnie ukazuje Puszczę Białowieską przez pryzmat dychotomii życia i śmierci:

Puszcza ma [...] imponujący wiek 6-8 tysięcy lat, choć poszczególne jej elementy są młodsze. Obok siebie żyją w niej organizmy o różnej fizjologicznej długości życia: od jednodniowej po kilkusetletnią. Puszcza w każdym momencie jest młoda, dojrzała i stara. [...] Na pierwszy rzut oka bowiem nie zauważa się, że w bliskim sąsiedztwie olbrzymiej sosny i dziuplastej dwustuletniej lipy, wokół porośniętego kożuchem mchów dębu, który padł w wieku pięciuset lat, zieleni się wielokrotnie liczniejszy gąszcz młodzieży i siewek [SPB, s. 424].

Dopiero doświadczenie życia w Puszczy pozwoliło dostrzec jej żywotność, pierwsza konfrontacja z dziką przyrodą wywołała bowiem zgoła inne wrażenie:

Wspaniały był pierwszy pobyt w Puszczy Białowieskiej. Przyjechałam tu, szukając pracy, na rekonesans, i to był listopad. I gdyby ktoś chciał kogoś zrazić do puszczy, to powinien go przywieźć w listopadzie. Bo jest to las niżowy, z przewagą liściastych. Ja duchowo i estetycznie byłam wychowana na lesie górskim. To jest zupełnie coś innego, on jest cały rok śliczny, natomiast niżowe lasy liściaste, jak już opadną im liście, to wszystko gnije, to jest beznadziejne, melancholijne, smutne i - co tu dużo mówić - brzydkie. I przyjechałam tu rozmawiać z kierownikiem placówki, żeby się zatrudnić, i po południu miałam czas, więc gdzież ja oczywiście skierowałam kroki? Pobiegłam szybciutko do bramy rezerwatu ścisłego, żeby przynajmniej zajrzeć przez płot, zobaczyć, jak też ta cudowna Puszcza Białowieska wygląda, no i wyglądała fatalnie. I to było moje pierwsze spotkanie z puszczą i sobie pomyślałam: kurcze, ale ten las to nie dla mnie. $W$ związku z tym ja tu przyjadę, ale tylko na trzy lata. Zrobię szybciutki doktoracik i fru w Bieszczady ${ }^{32}$.

Pierwsze spotkanie Kossak z lasem zniechęciło ją do puszczańskiej przyrody, jednak kolejne lata spędzone na Dziedzince utwierdziły ją w przekonaniu, że Puszcza Białowieska ,żyje [...] tak długo, dopóki wyrasta z prochów poprzednich pokoleń, a cykle narodzin i naturalnej śmierci trwają nieprzerwanie tysiące lat" [SPB, s. 465]. Doświadczenie życia w lesie łączy się również ze zdobywaniem wiedzy o charakterze pracy leśników, na których puszcza robi „wrażenie nieuporządkowanej, przegęszczonej trupiarni z tysiącami marniejących dziuplastych i zahubionych przestojów" [SPB, s. 425].

32 A. Kamińska, Simona. Opowieść o niezwyczajnym życiu Simony Kossak, Kraków 2015, s. 129. 
To wrażenie wszechobecnej śmierci wywołują w Puszczy zarówno gnijące drzewa, jak również bardzo duża liczba kurhanów, stanowiących obiekt prac archeologicznych ${ }^{33}$. Ewa Domańska w książce Nekros. Wprowadzenie do ontologii martwego ciała stwierdza, że „u postaw idei Nekrosu stoi teoria nekro-witalizmu, tj. powstawania życia z materii martwej" ${ }^{34}$. Naturalne cykle życia i śmierci, opisywane przez Kossak, pozwalają rozumieć Puszczę jako miejsce nekrowitalne. $Z$ koncepcją nekrowitalności łączy się nierozerwalnie kategoria sprawczości, która w ujęciu Domańskiej, powołującej się na rozważania Bruno Latoura ${ }^{35}$, ma charakter relacyjny:

ważny jest nie tyle sprawca/aktor i jego status, ile jego miejsce $\mathrm{w}$ sieci relacji, a także badanie połączeń i ich zmian (rozpadania się związków i ponownego ich splatania). Sprawstwo zaś to wypadkowa działania wielu aktorów - czynników ludzkich i nie-ludzkich, które same w sobie są podmiotami zbiorowymi ${ }^{36}$.

Rozpatrywanie roślin i zwierząt Puszczy Białowieskiej w kontekście ich sprawczości sprawia, że stają się one równouprawnionymi aktorami w sieci relacji. O sprawczym charakterze roślin Kossak pisałam w kontekście jej Opowiadań ${ }^{37}$. Dekonstruując w Sadze legendę opiekuńczych polskich władców, którym przez lata kolejni badacze przypisywali zasługi zachowania resztek Puszczy Białowieskiej, autorka dochodzi do wniosku, że to „bezbronnym ofiarom królów i carów, zawdzięcza Puszcza Białowieska swoje przetrwanie" [SPB, s. 166]. Przez „bezbronne ofiary" rozumieć należy niedźwiedzie, żubry, jelenie i inne zwierzęta, które w wyniku nie tylko kłusownictwa czy hobbystycznego myślistwa, ale również królewskich polowań, stopniowo zniknęły z Puszczy. W powszechnej opinii zachowanie Puszczy Białowieskiej przypisywane jest królewskim i carskim łowom, jednak w przekazie Kossak zasługi należy przypisać raczej ofiarom łowów, a nie myśliwym.

33 "Znajduje się ono [cmentarzysko - dop. K.T.] przy dawnym torze kolejki z czasów pierwszej wojny światowej, na północ od drogi wiodącej z leśniczówki na wschód. Dwa kurhany $\mathrm{z}$ tego cmentarzyska zostały rozkopane przez A. Kleina w okresie międzywojennym. W dokumentacji brak jest niestety planu sytuacyjnego i dokładniejszych danych odnośnie do położenia tego cmentarzyska, co daje się dotkliwie odczuć wobec licznego nagromadzenia cmentarzysk kurhanowych na terenie całej Puszczy" [E. Walicka, Wczesnośredniowieczne kurhany w Puszczy ladzkiej pow. Bielsk-Podlaski, „Wiadomości Archeologiczne” 1958, t. 25, z. 1-2, s. 158].

34 E. Domańska, Nekros. Wprowadzenie do ontologii martwego ciała, Warszawa 2017, s. 7.

35 „Każda rzecz, która zmienia stan rzeczy, która wprowadza jakąś różnicę, jest aktorem”. Zob. B. Latour, Splatając na nowo to, co społeczne. Wprowadzenie do teorii aktora-sieci, przeł. K. Arbiszewski, A. Derra, Kraków 2010, s. 100.

36 E. Domańska, Nekros, s. 63.

37 Zob. K. Trusewicz, Herbstory/herstory w wydaniu Simony Kossak, „Białostockie Studia Literaturoznawcze" 2018, nr 12, s. 251-265. 
Tym samym sprawstwo zostało przez nią przypisane zwierzętom. Domańska stwierdza, że ekologiczna historia ratownicza „poszukuje [...] nowatorskich form sprawstwa które nie ograniczają się do działalności człowieka, lecz upatrują go także w czynnikach nie-ludzkich - zwierzętach, roślinach, rzeczach, a także w dźwięku czy świetle" ${ }^{38}$. Dzięki przyjęciu przez Kossak nieantropocentrycznej perspektywy zwierzęta zostały zaprezentowane nie tylko jako ofiary czy zdobycze, ale przede wszystkim jako dostarczyciele argumentów na rzecz obrony ostatnich puszczańskich ostępów.

Bliski kontakt ludzi z lasem doprowadził do wykształcenia w polskim systemie językowym szeregu „leśnych" określeń, takich jak bory, ostępy, bagna, olsy, hrydy, doliny, chruśniaki, łozy, ostępy czy gaje. Wyjątkową umiejętność językowego obrazowania puszczańskiej przyrody posiadała Eliza Orzeszkowa, czemu dała wyraz w powieści $A d$ astra ${ }^{39}$. Wiedzę o specyfice przyrody Puszczy Białowieskiej zdobywała w trakcie kilku turystyczno-badawczych wizyt. W przypadku Simony Kossak życie w leśniczówce Dziedzince usytuowanej na puszczańskiej polanie wpłynęło na język, jakim posługiwała się w swoich utworach. Saga, którą - jak sama deklaruje - stara się spłacić dług wdzięczności wobec Puszczy, nie obfituje w pastoralne opisy przyrody, które znamy z tradycji literatury romantycznej. Przyrodopisarka, wykorzystując bogatą wiedzę ekologiczną, ubiera ją w literacki kostium. W rozdziale Puszcza znajduje się następujący fragment:

Oto najszlachetniejszy z lasów - puszczański grąd. [...] Przestrzeń między dnem grądu a błękitem nieba wypełnia zielone bogactwo. Nad wszystkim górują, jak wieżyce i baszty, czuby najstarszych świerków, dębów, jesionów i lip. Pod nimi rozpościera się dach lasu zbudowany z koron klonów, grabów, wiązów, brzóz, a niekiedy i olsz. Krok w dół i oto królestwo leszczyny, trzmieliny i pnącego się ku światłu młodego pokolenia drzew. Tłoczno jest również na samym dnie grądu; tu królują byliny: kępy bujnych traw i paproci, łany podagrycznika, pokrzyw i czosnku niedźwiedziego, jaskier kosmaty, kokorycz. Niżej rosną zastępy gwiazdnicy wielkokwiatowej, gajowca żółtego, groszku wiosennego, turzycy orzęsionej i skrzypu. Miejscem przy samej ziemi zadowalają się kopytnik, miodunka ćma, przylaszczka, majownik dwulistny, szczawik zajęczy, fiołek leśny [SPB, s. 27-28].

Kossak opisuje Puszczę w porządku wertykalnym, wydzielając jej poszczególne poziomy. Opis puszczańskiego grądu przywołuje skojarzenie z wielopokoleniową rodziną. Najwyższy poziom stanowią najstarsze drzewa, po-

\footnotetext{
38 E. Domańska, Nekros, s. 212.

39 Zob. E. Orzeszkowa, J. Romski (właśc. Tadeusz Garbowski), Ad astra. Dwugłos, Warszawa
} 1950. 
równane do wież i baszt, które górują nad pozostałymi i niejako strzegą niższych braci. Kolejną warstwę stanowi dach lasu zbudowany z koron różnego rodzaju drzew chroniących "młodzież lasu”, młode pokolenie. Dno lasu reprezentują różnego rodzaju byliny oraz zioła, które porównać można do najmłodszych dzieci, chowających się u stóp swych rodziców.

Anna Nacher w artykule Las - wspólnota sympoietyczna?, omawiając książkę Petera Wohllebena Sekretne życie drzew, zauważa, iż język autora jest silnie antropomorficzny i zastanawia się, „[c]zy coś może się istotnie zmienić $\mathrm{w}$ naszych relacjach $\mathrm{z}$ przyrodą, jeśli będziemy tkwili $\mathrm{w}$ obrębie tych samych metafor kształtujących myślenie o świecie" ${ }^{40}$. Analiza twórczości literackiej Simony Kossak prowadzi do wniosku, że badaczka w swoich wypowiedziach posługiwała się popularnymi metaforami oraz skojarzeniami. Kossak skrupulatnie wymienia nazwy poszczególnych roślin, które czytelnikowi niezaznajomionemu z bogactwem puszczańskiej roślinności mogą nie mówić nic konkretnego, jednak warto zwrócić uwagę na ich poetycki potencjał $^{41}$. Jedną z popularnych metafor, do której odwołuje się Simona Kossak, jest personifikacja przyrody jako kobiety:

A poroniona Puszcza, do mineralnej gleby oskalpowana $\mathrm{z}$ lasu naturalnego, bohatersko walczyła $\mathrm{z}$ hodowcami drzew gospodarczo cennych o zregenerowanie swej różnorodności biologicznej. Wysiewała na zrębach "chwasty upraw leśnych" wonne trawy i zioła oraz lekkonasienne liściaste drzewa i krzewy, przygłuszając sztucznie wyhodowane w szkółce wątłe sadzonki sosny. Chciała, swoim zwyczajem, najpierw nawieźć glebę murszem krótkowiecznych drzew, by dać lepsze możliwości rozwoju swoim długorosnącym, ekologicznie cennym olbrzymom: dębom, lipom i jesionom [SPB, s. 436].

Kossak, krytyczna wobec zachowań człowieka względem Puszczy, przypisując jej kobiecą płeć, stara się uzmysłowić eksploatacyjny charakter panującej relacji. Przejawia się to szczególnie we fragmentach Sagi poświęconych myślistwu, które również postrzega przez pryzmat kategorii płci:

Mroczne są tajniki duszy ludzi przekonanych, że rozpędzanie tokowisk i ładowanie ołowiu w bezradne ptaki, które szczęśliwie przezimowały i zamierzały właśnie przedłużyć istnienie gatunku, jest czymś pożytecznym, nobilitującym i szlachetnym, czym można się szczycić. W podobny zresztą sposób niektórzy

\footnotetext{
40 A. Nacher, Las - wspólnota sympoietyczna?, "Czas Kultury” 2017, nr 3, s. 8.

41 O poetotwórczym potencjale nazw roślin, w kontekście Opowiadań Simony Kossak, pisał Michał Książek w eseju Podróż do tutaj. Zob. M. Książek, Podróż do tutaj, online: https://www. dwutygodnik.com/artykul/7071-podroz-do-tutaj.html [dostęp 9.03.2021].
} 
myśliwi, najczęściej mężczyźni, załatwiają swoje porachunki z innymi zwierzętami, do niedawna zabijając $\mathrm{w}$ czasie godów cietrzewie, bataliony i jarząbki, a do dziś - słonki, dzikie kaczki, sarny, jelenie i łosie [SPB, s. 386].

Poruszając w swojej twórczości temat myślistwa, Kossak wielokrotnie podkreśla fakt, że jest typowo męską aktywnością ${ }^{42}$, która ma na celu podkreślenie dominacji człowieka-mężczyzny nad przyrodą-kobietą. Warto zauważyć, że takie postrzeganie myślistwa jest ukształtowane kulturowo, $\mathrm{z}$ badań archeologicznych wynika bowiem, że w starożytności kobiety polowały na równi z mężczyznami ${ }^{43}$.

Puszcza Białowieska jako teren atrakcyjny łowiecko stała się obiektem myśliwskiego zainteresowania premiera Prus Hermanna Göringa, uhonorowanego m.in. najważniejszym odznaczeniem Polskiego Związku Łowieckiego. Göring był wielokrotnym gościem w Puszczy Białowieskiej, a w 1936 roku brał udział w reprezentacyjnym polowaniu prezydenta Ignacego Mościckiego ${ }^{44}$. Rok później w Berlinie miała miejsce Międzynarodowa Wystawa Łowiecka, na której jednym z najbardziej popularnych stanowisk był pawilon dotyczący Puszczy Białowieskiej. Ostatecznie „marszałek Rzeszy Niemieckiej, główny organizator gestapo i obozów koncentracyjnych, zbrodniarz wojenny - Hermann Göring przestał czuć się gościem w Puszczy Białowieskiej. W czerwcu 1941 roku otrzymał ją do swojej dyspozycji jako Reichjagdgebiet” [SPB, s. 370], choć przez cały okres okupacji „nie pojawił się w «swojej» Białowieży" [SPB, s. 379]. W fascynacji Göringa terenami łowieckimi Puszczy Białowieskiej i chęci posiadania tej przestrzeni na własność Kossak upatruje przyczyn wybuchu drugiej wojny światowej, co pozwala rozpatrywać Puszczę jako nieintencjonalnego sprawcę.

Simona Kossak nie bała się stanąć przeciw wszystkim i walczyć o swoje poglądy. Przykładem jej zaangażowanej postawy może być wystąpienie podczas otwarcia wystawy „Roku Myśliwca” w 1987 roku. W trakcie uroczystości Kossak, zaproszona jako potomkini pasjonatów myślistwa, wyraziła katego-

42 Zob. również: „Żył tu [jeleń europejski - dop. K.T.] niezagrożony do czasu, gdy w puszczy pojawił się najgroźniejszy wróg dzikich zwierząt: łowca i osadnik spragniony mięsa, skór i męskiej rozrywki" [SPB, s. 175].

43 Zob. K. Mazur, Gród łowczyni sprzed 9 tys. lat dowodzi, że kobiety polowały na równi z mężczyznami, online: https://www.national-geographic.pl/artykul/grob-lowczyni-sprzed-9-tys-latdowodzi-ze-kobiety-polowaly-na-rowni-z-mezczyznami [dostęp 10.03.2021].

44 O polsko-niemieckich polowaniach dewizowych w ramach optyki postzależnościowej zob. M. Zduniak-Wiktorowicz, W przyrodzie nic nie ginie, czyli polsko-niemieckie kontakty ekokulturowe na przykładzie literatury z polowan, w: Centra-peryferie w literaturze polskiej XX i XXI wieku, red. W. Browarny, E. Rybicka, D. Lisak-Gębala, Kraków 2015, s. 436-453. 
ryczny sprzeciw wobec praktyk łowieckich ${ }^{45}$. Ton jej wypowiedzi był stanowczy i zdecydowany, a w Sadze wypowiada się w sposób równie krytyczny, pisząc na przykład o "kabotyńskim i obrzydliwym polowaniu” [SPB, s. 250]. Stanowisko badaczki zaangażowanej w ochronę przyrody było krytyczne wobec myśliwych. Lekturze Sagi Puszczy Białowieskiej towarzyszy przeświadczenie, że autorka była pełna dezaprobaty wobec całego gatunku homo sapiens. Wynika to z pewnością z faktu, iż Kossak koncentruje się głównie na negatywnych aspektach obecności człowieka w Puszczy Białowieskiej, prowadzącej nie tylko do sukcesywnego zmniejszania się jej powierzchni, ale również do wyginięcia na jej obszarze żubrów czy niedźwiedzi. Opisując w opowiadaniu Perkun losy zamieszkujących Puszczę Białowieską niedźwiedzi, autorka stara się uświadomić czytelnikowi, że pomysł ponownego sprowadzenia tego gatunku w ostępy Puszczy jest nieodpowiedzialny. Powodem, dla którego niedźwiedzie nie powinny powrócić do Puszczy, jest, według Kossak, obecność w niej wrogo nastawionych wobec nich ludzi, co potwierdza nieudana próba przywrócenia Puszczy niedźwiedzia brunatnego w latach 1937-1939:

Za swe zaufanie do ludzi drogo zapłaciły. Samiczka i imieniu Czarna [...] powędrowała polami i lasami aż na omelenieckie łąki w nadleśnictwie Bielsk Podlaski. Tu dopadli ją uzbrojeni w koły i siekiery mieszkańcy gminy Wierzchowice ze wsi Grybel, Smolatyn i Klatkowo. Ciężko ranna, z prawie odciętą lewą łapą, uciekając przez pastwiska stratowała jagnię. Wówczas rozwścieczeni chłopi otoczyli ją i zmasakrowali na krwawą miazgę [SPB, s. 84].

Okrucieństwo mieszkańców wiosek położonych wokół Puszczy Białowieskiej w stosunku do ufnego zwierzęcia poskutkowało jego śmiercią. Wyczulona na dobro zwierząt Kossak twierdzi, że „pomysłowość ludzka w dręczeniu zwierząt nie ma granic" [SPB, s. 120], a „los oswojonych, ufnych zwierząt chodzących samopas po Puszczy jest zawsze taki sam - szybko padają ofiarą zachłanności i okrucieństwa człowieka" [SPB, s. 142]. Autorka zdaje sobie sprawę z faktu, iż antropopresja doprowadziła do tak dużych zmian w przyrodzie, że myśl o powrocie do stanu pierwotnego jest utopią.

45 „Szczególnym łącznikiem pomiędzy Juliuszem, Polem i mną jest łowiectwo. Mam jednak określone zdanie na temat zabijania dzikich zwierząt, oparte nie tylko na emocjach, lecz także na faktach naukowych. Rozpatrując polowania od strony etycznej, uważam, że zabijanie zwierząt wyłącznie dla rozrywki było i jest niegodne człowieka cywilizowanego. Mam pod ręką garść wspomnień łowieckich różnych - nawet wspaniałych autorów - i wszystkie budzą wstręt swoją obłudą i okrucieństwem. Obłudą, bo panowie udają, że kochają przyrodę, a zwierzęta szczególnie, a okrucieństwem, bo po zachwytach: „jaki on silny i śliczny" następuje scena mordu niewinnej ofiary. Poglądy na myślistwo Pola i Juliusza Kossaka potępiam" [A. Kamińska, Simona, s. 208]. 
Saga Puszczy Białowieskiej wyrasta z przekonania Kossak, iż:

las wyhodowany przez człowieka tak się ma do puszczy, jak krowa do żubra, jak kundel wiejski do wilka, jak Puszcza Notecka, Kampinoska i Niepołomicka do Puszczy Białowieskiej. Jak tombak do złota. Ona - ogromna, dzika i wolna - nie potrzebuje nas, by trwać przez dalsze tysiąclecia, nie potrzebuje naszych pił i rachitycznych sadzonek [SPB, s. 12].

Autorka Sagi była przekonana o wyjątkowości opisywanego przez nią miejsca, któremu poświęciła swoją aktywność naukową oraz literacką. Jako bezpośredni świadek postępującej degradacji puszczańskiego krajobrazu zdawała sobie sprawę, że osobom oraz instytucjom eksploatującym Puszczę zależy na tym, aby ludzie zainteresowani jej losem nie wiedzieli, "co zrobiono z "puszczą» ukrytą za gęstą firanką wąskiego pasa starych drzew pozostawionych na pniu $\mathrm{w}$ «rezerwacie krajobrazowym imienia profesora Szafera» wzdłuż szosy Hajnówka-Białowieża" [SPB, s. 443]. Kossak uznała, że jedną z metod walki z wciąż powracającym problemem wycinki Puszczy Białowieskiej będzie napisanie książki i opublikowanie jej nie tylko w języku polskim, ale też $\mathrm{w}$ angielskim ${ }^{46}$, umożliwiającym dotarcie do międzynarodowej społeczności. Tym samym Sagę Puszczy Białowieskiej należy rozpatrywać jako sprawczą - jest to dzieło edukujące i uwrażliwiające, jak również rodzaj alternatywnej historii Puszczy, włączającej perspektywę nieantropocentryczną. Mimo faktograficznej wartości Sagi Kossak nie nadaje swojej narracji obiektywności i racjonalności w ich oświeceniowym rozumieniu. Tę kojarzy bowiem z eksploatacyjnym i patriarchalnym myśleniem o przyrodzie. Nieskrywana subiektywność Sagi służy Kossak do opowieści o podmiotach nie-ludzkich z perspektywy podmiotu empatycznego, zaangażowanego i usytuowanego w konkretnym miejscu.

\section{Bibliografia}

Barcz Anna (2016), Realizm ekologiczny. Od ekokrytyki do zookrytyki w literaturze polskiej, Katowice: "Sląsk" Wydawnictwo Naukowe.

Dąbkowski Przemysław (1923), Bartnictwo w dawnej Polsce. Szkice gospodarczo-prawne, Lwów.

Domańska Ewa (2017), Nekros. Wprowadzenie do ontologii martwego ciała, Warszawa: Wydawnictwo Naukowe PWN.

46 S. Kossak, The Białowieża Forest Saga, Warszawa 2001. 
Durczak Joanna (2010), Rozmowy z ziemia. Tradycja przyrodopisarska w literaturze amerykańskiej, Lublin: Wydawnictwo Uniwersytetu Marii Curie-Skłodowskiej.

Głowiński Michał, Kostkiewiczowa Teresa, Okopień-Sławińska Anna, Sławiński Janusz (1988), Słownik terminów literackich, Wrocław: Zakład Narodowy im. Ossolińskich.

Hademann Otton (1939), Dzieje Puszczy Białowieskiej w Polsce przedrozbiorowej (w okresie do 1798 roku), Warszawa: skł. gł. Księg. Rolnicza.

Kamińska Anna (2015), Simona. Opowieść o niezwyczajnym życiu Simony Kossak, Kraków: Wydawnictwo Literackie.

Kossak Simona (1992), Śmierć puszczy, „Gazeta Wyborcza”, nr 136, s. 12.

Kossak Simona (1995), Opowiadania o ziołach $i$ zwierzętach. Zgodnie z natura swojego gatunku, Warszawa: Alfa-Wero.

Kossak Simona (2001), Saga Puszczy Białowieskiej, Warszawa: Muza.

Kossak Simona (2001), The Białowieża Forest Saga, Warszawa: Muza.

Kossak Simona (2016), Saga Puszczy Białowieskiej, Warszawa: Wydawnictwo Marginesy.

Kossak Simona (2017), O ziołach i zwierzętach, Warszawa: Wydawnictwo Marginesy.

Książek Michał, Podróż do tutaj, https://www.dwutygodnik.com/artykul/7071podroz-do-tutaj.html [dostęp 9.03.2021].

Lachman Magdalena (2011), Gdzie jest przyroda, jak jej... nie ma? Rzut oka na przypadek literacki, „Kultura Współczesna”, nr 1, s. 137-149.

Latour Bruno (2010), Splatajac na nowo to, co społeczne. Wprowadzenie do teorii aktora-sieci, przeł. K. Arbiszewski, A. Derra, Kraków: Universitas.

Lelewel Joachim (1856), Pszczoły i bartnictwo w Polszcze, Poznań: J.K. Żupański.

Mazur Katarzyna, Gród łowczyni sprzed 9 tys. lat dowodzi, że kobiety polowały na równi z mężczyznami, https://www.national-geographic.pl/artykul/grob-lowczynisprzed-9-tys-lat-dowodzi-ze-kobiety-polowaly-na-rowni-z-mezczyznami [dostęp 10.03.2021].

Nacher Anna (2017), Las - wspólnota sympoietyczna?, „Czas Kultury”, nr 3, s. 6-12.

Nycz Ryszard (1984), Sylwy wspótczesne. Problem konstrukcji tekstu, Wrocław: Zakład Narodowy im. Ossolińskich - Wydawnictwo Polskiej Akademii Nauk.

Orzeszkowa Eliza, Romski Juliusz (właśc. Tadeusz Garbowski) (1950), Ad astra. Dwugłos, Warszawa: Książka i Wiedza.

Romaniuk Radosław (2002), Samotny mamut, „Nowe Książki”, nr 7-8, s. 12-13.

Samojlik Tomasz (2014), Las a rozwój człowieka w dziejach cywilizacji (na przykładzie Puszczy Białowieskiej), w: Las jako czynnik rozwoju cywilizacji: współczesna i przyszła wartość lasów, red. K. Rykowski i in., Sękocin Stary: Instytut Badawczy Leśnictwa.

Samojlik Tomasz [red.] (2005), Ochrona i łowy. Puszcza Białowieska w czasach królewskich, Białowieża: Zakład Badania Ssaków Polskiej Akademii Nauk.

Skwarczyńska Stefania (1970), Kariera literacka form rodzajowych bloku silva, w: S. Skwarczyńska, Wokót teatru i literatury. Studia i szkice, Warszawa: „Pax”, s. 182-202.

Trusewicz Katarzyna (2016), Ekogawędy Simony Kossak, „Białostockie Studia Literaturoznawcze", nr 9, s. 95-105. 
Trusewicz Katarzyna (2018), Herbstory/herstory w wydaniu Simony Kossak, „Białostockie Studia Literaturoznawcze", nr 12, s. 251-265.

Ubertowska Aleksandra, Pisanie puszczy. Ekonomie dyskursu ekokrytycznego i postkolonialnego, „Teksty Drugie” 2017, nr 6, s. 193-208.

Walicka Elżbieta (1958), Wczesnośredniowieczne kurhany w Puszczy ladzkiej pow. Bielsk-Podlaski, „Wiadomości Archeologiczne”, t. 25, z. 1-2, s. 157-158.

Zduniak-Wiktorowicz Małgorzata (2015), W przyrodzie nic nie ginie, czyli polsko-niemieckie kontakty ekokulturowe na przykładzie literatury z polowan, w: Centra-peryferie w literaturze polskiej XX i XXI wieku, red. W. Browarny, E. Rybicka, D. Lisak-Gębala, Kraków: Universitas, s. 436-453.

\title{
Nature in a Non-athropocentric Perspective: On Saga Puszczy Białowieskiej by Simona Kossak
}

\begin{abstract}
The article offers a non-anthropocentric reading of Simona Kossak's Saga Puszczy Białowieskiej. It also examines the context of scholarly research into the human activity in the Białowieża Primeval Forest (Otton Hademann, Tomasz Samojlik). The author of the article looks at the generic characteristics of this volume and observes that by using her knowledge of nature and history, Kossak gives her saga a character of a palimpsest and deconstructs certain stereotypes and legends concerning the Forest, including both its human and non-human residents. The author also refers to Kossak's biography and points to the writer's ethical engagement to prevent the destruction of the natural environment of the Forest.
\end{abstract}

Keywords: saga, silva rerum, primeval forest, athropo-pressure, necrovitality 